\title{
CENAS MILITARES: IDENTIDADE, HIERARQUIA E MORAL NO COMPLEXO
}

DO ALEMÃO

Clark Mangabeira ${ }^{1}$

\section{RESUMO}

A relação entre indivíduo e sociedade está no cerne das questões das Ciências Sociais. O objetivo deste trabalho é elucidar como determinas cenas e figuras nas vidas dos indivíduos são conceitos potentes para a determinação de suas escolhas e interações sociais. No caso em pauta, procuramos entender como a identidade militar e os conceitos de hierarquia e moralidade decorrentes daquela identidade podem ser entendidos a partir de momentos nos quais a carreira identitária é fundamental, no caso, a invasão do Complexo do Alemão, em 2010, momento que serviu tanto para manter e reafirmar, quanto de polo de reflexão da vida militar de Paulo.

Palavras-chave: Militarismo; Identidade; Hierarquia; Moral; Complexo do Alemão (RJ)

\section{MILITARY SCENES: IDENTITY, HIERARCHY AND MORALITY IN THE}

"GERMAN COMPLEX"

\begin{abstract}
The relationship between individual and society is at the heart of the issues of Social Sciences. The objective of this study is to elucidate how certain scenes and figures in the lives of the individuals are powerful concepts for the determination of their choices and social interactions. In the case at hand, we are trying to understand how the military identity and its related concepts of hierarchy and morality could be understood from moments in which the identity career is crucial, like the case of the invasion of the German Complex in 2010, which served both to maintain and reaffirm Paulo's identity and as the pole of reflection of his military life.
\end{abstract}

Keywords: Militarism; Identity; Hierarchy; Morality; The "German Complex (RJ)"

${ }^{1}$ Doutorando em Antropologia Social no Museu Nacional da Universidade Federal do Rio de Janeiro.

INTRATEXTOS, Rio de Janeiro, 4(1): 258-276, 2012.

Página 258 
"De qualquer forma, minha catarse foi a carreira militar", disse-me Paulo em uma das nossas inúmeras entrevistas. "Eu sempre sonhei em ser militar no final das contas, mas meu pai me pressionava muito e eu tinha raiva... até hoje amo e odeio minha profissão".

Paulo é um jovem branco no começo dos seus trinta anos. Casado com uma acadêmica, mora há cerca de dois anos no Rio de Janeiro. Filho de militares, descendente de europeus, a opção por ingressar na carreira foi uma construção feita ao longo da sua vida e influenciada pela sua família, paralelo à sua escolha em ter uma formação superior: antes do seu treinamento, ele cursava Direito em uma universidade pública, curso que abandonou por não gostar. Atualmente, em outra universidade, é aluno da faculdade de História.

Conheci Paulo no começo de 2011: um rapaz alto, fechado, mas simpático, de corpo atlético, inteligente e com um apetite voraz para crescer na vida. Vindo do sul do Brasil, a "catarse" a que se refere, principalmente quando se lembra da sua relação com os oficiais, define rotineiramente sua vida profissional e pessoal. Embora seu grande sonho seja participar de forças ou comandos especiais, é a hierarquia e as mazelas da segurança pública brasileira que desmotivam suas ambições: "aqui, a gente é tratado igual a um coitado", confidencioume.

Na sua trajetória profissional, a invasão do Complexo do Alemão no Rio de Janeiro, no final de 2010, foi um marco. Paulo não foi convocado para o cerco: ele voluntariou-se. A primeira vez que ele mencionou a significação deste trabalho para sua vida foi logo após uma discussão com sua esposa. Embora já houvéssemos conversado sobre alguns eventos ocorridos durante a ocupação, apenas nesta ocasião ele afirmou que a insatisfação com a vida militar aumentara após a missão: “eu sou um 'soldado', meu relacionamento com a carreira é de amor e ódio... mas ultimamente 'tô' ladeira abaixo em motivação... desiludido... o processo aumentou no Alemão... encaro diariamente um apartheid velado no trabalho". A pergunta que reluzia para mim era o que é ser militar? Ou melhor, quais situações definem esta identidade e os problemas que ela traz? O objetivo deste ensaio é, portanto, focar na constituição da identidade militar de Paulo via as situações que, segundo ele, estão latentes na sua memória.

A tarefa desenrola-se por dois caminhos: primeiro, para entendermos a relação de Paulo, enquanto praça graduado, com os oficiais superiores, focaremos em algumas cenas que ocorreram antes e durante a invasão do Alemão e que dramatizam aquela relação hierárquica. 
Segundo, a fim de elucidarmos o sentido mais geral do que é ser militar e da moral envolvida, além do significado de uma missão real vista a partir de um de seus agentes, estabeleceremos uma continuidade entre eventos da vida do nosso soldado e características mais gerais que ele evoca sobre o militarismo, buscando-se a construção social da sua realidade, a partir da interação entre os níveis micro e macro da vida social.

A. L. Epstein (1969) chama atenção para o fato de que no domínio citadino, metropolitano, a quantidade de características dominantes presentes neste contexto heterogeneidade, grande densidade populacional, mobilidade, desenvolvimento econômico e social - parece ressaltar um estado de fluxo inerente da vida na cidade, fato que, por vezes, é caracterizado como uma aparente confusão da cena urbana, como reflexo de uma mera agregação de indivíduos. Contudo, segue o autor, há um mínimo de ordem social, uma organização na qual cada indivíduo está preso a uma rede de laços sociais que definem a identidade daqueles em seu interior.

Partindo do pressuposto de que a identidade (e a moralidade) é definida socialmente, dialogicamente, uma entidade sempre em construção, a ideia de rede social pode ser chave não apenas como pressuposto metodológico, mas como entreposto teórico de definição da pergunta que buscamos entender: ser militar, assim, só pode ser entendido se levarmos em conta a posição hierárquica do ator social em análise, de modo que todas as suas ações são entrecortadas pelo estrato no qual ele se encontra. Neste sentido, as situações vividas, bem como a definição do militarismo que Paulo defende, só fazem sentido se entendidas diante do fato, primeiro, de que a ideia de rede é egocêntrica, ou seja, é definida em relação a apenas um indivíduo, e segundo, de que se trata de um praça graduado em interação com oficiais superiores, patentes subordinadas e outros iguais, cuja moralidade, que dá sentido às suas ações, definiu-se muito antes, em outras interações que servem de base para quem Paulo diz ser, mas que é atualizada rotineiramente, contextualmente, situacionalmente.

A identidade nunca é estática, plana, chapada. Segundo Gilberto Velho (2003; 2008), a característica principal das sociedades complexas seria a coexistência de diferentes estilos de vida e visões de mundo que se relacionam - uma pluralidade de tradições que se cruzam - e a possibilidade de trânsito entre eles, o que pode ser resumido na idéia de heterogeneidade cultural. Qualquer sociedade apresenta tensões, historicamente determinadas, entre a particularização e a universalização das experiências individuais, entre um tipo de holismo e um tipo individualismo construídos socioculturalmente, de modo que a complexidade resvala na forma como os indivíduos participam de códigos mais restritos ou mais universalizantes. 
Sendo a realidade das pessoas culturalmente construídas, a incoerência e o multiculturalismo fazem parte do cenário. "Não há cultura que não seja um conglomerado resultante de acréscimos diversificados" (Barth, 2000, p. 109) e, assim, os modos pelos quais os agentes sociais agem são marcados pela participação em diversos mundos, em discursos múltiplos interdependentes, em "correntes de tradições culturais" (Barth, 2000, p. 123) que não decorrem de uma única fonte. A definição de Paulo sobre sua própria vida não está imune às tensões e incoerências que caracterizam o mundo social como um todo: ser militar, portanto, abrange ao mesmo tempo uma "relação de amor e ódio".

Assim, ao contrário da rede social que Epstein definiu a partir de Chanda, observada em fluxo no ínterim dos encontros do seu protagonista com conhecidos pelas ruas da cidade, o aspecto que usamos do seu conceito é seu lado mais geral, mais amplo, qual seja, o de que "each person sees himself at the center of a collection of friends. Is follows therefore that the network is always 'personal', for the set of links that make it up are unique for each individual" (Epstein, 1969, p. 109). Para entendermos a identidade do nosso soldado, estabelecemos como ponto de partida as relações que ele teve com uma pessoa de grande intensidade que surge como central na constituição da sua identidade militar em seu aspecto positivo, moralizado. Na sua rede social efetiva, ou seja, naquela em que é tendência a minimização da diferenciação de status, seu pai - e o contato com seus amigos de mesma "hierarquia" - definiu a experiência que Paulo teve e tem dentro da carreira no polo positivo, ao passo que, a interação com seus superiores dentro da sua rede estendida, na qual as diferenças sociais e hierárquicas são operantes, revelam o lado negativo de ser militar.

Neste sentido, é na interface entre sua biografia pessoal e a realidade social que o desenrolar da sua identidade militar ganha contornos. Para estabelecermos o link, como definiu Wright Mills, é a imaginação sociológica que nos possibilita articular as dimensões micro e macro da realidade social, podendo-se compreender a esfera individual a partir do plano social e vice versa. Tal dinâmica nos permite ir do íntimo do ser humano para a estrutura histórica e social sem perdermos de referência nenhum dos dois polos, mantendo a percepção de retroalimentação das duas esferas:

A imaginação sociológica capacita seu possuidor a compreender o cenário histórico
mais amplo, em termos de seu significado para a ida íntima e para a carreira exterior
de numerosos indivíduos. Permite-lhe levar em conta como os indivíduos, na
agitação da sua experiência diária, adquirem freqüentemente uma consciência falsa
de suas posições sociais. Dentro dessa agitação, busca-se a estrutura da sociedade
moderna, e dentro dessa estrutura são formuladas as psicologias de diferentes
homens e mulheres. [...] O primeiro grande fruto dessa imaginação - e a primeira 
lição da ciência social que a incorpora - é a idéia de que o individuo só pode compreender sua própria experiência e avaliar seu próprio destino localizando-se dentro de seu período; só pode conhecer suas possibilidades na vida tornando-se cônscio das possibilidades de todas as pessoas, nas mesmas circunstâncias que ele (Mills, 1982, p. 11/12).

Mas como realizar este empenho? O ponto de Mills é o de que entender uma estória, um fragmento da vida de um agente social, envolve sua ligação a estruturas sociais mais amplas que dão o tom do contexto em que ele se encontra. A imaginação sociológica opera como um catalisador das experiências pessoais em função dos códigos e interações a que estão vinculados, mas também atua na forma como os agentes sociais definem suas situações, como eles pensam suas vidas, ou seja, nas margens dinâmicas a partir das quais as situações se modificam através da ação dos indivíduos: não é possível entender a complexidade da situação sem entender como essa situação é definida, bem como é infrutífero apreender os códigos independentemente da visão de mundo dos atores sociais. Nesse universo sincrético, deve-se buscar o grau de padronização sem perder de vista os diversos discursos que o compõem e a multiplicidade de padrões parciais que se interferem reciprocamente, nem se afastando das realidades dos agentes envolvidos.

J. Clyde Mitchell (1956) oferece parâmetros em termos metodológicos ao tratar da análise situacional em Antropologia. Partindo da dança Kalela, Mitchell conclui que a etnicidade urbana não é um simples elemento de continuidade da etnicidade tribal, transplantada para o novo contexto metropolitano, mas, antes, é uma criação urbana, um princípio classificatório misto que envolve elementos anteriores e posteriores à urbanização. O ponto nevrálgico que nos interessa é a definição da situação como forma de se abordar categorias culturais no seu contexto prático de realização, observada diretamente a partir das situações reais dos atores sociais. Apoiado em Evans-Pritchard, Mitchell defende que as crenças e lógicas de julgamento são atualizadas situacionalmente, cuja coerência é encontrada apenas no contexto que as elencou - em outras palavras, há seleções situacionais de significados e sentidos, de maneira que "colocado em uma determinada situação, um homem escolhe, dentre as crenças, aquelas que lhe convêm, e as utiliza sem prestar a mínima atenção aos outros elementos, ao passo que pode ocorrer-lhe se servir destes em situações diferentes" (Evans-Pritchard apud Agier, Michel, 2001, p. 13).

Consequentemente, a imaginação sociológica ganha densidade operacional a partir da abordagem situacional que Mitchell definiu. No caso de Paulo, sua identidade militar assume contornos ora positivos, ora negativos, dependendo da situação que sua memória ativa. 
Ademais, a avaliação da sua identidade e da moralidade de suas ações ocorre de acordo com os agentes sociais e as interações em questão. A relação de amor e ódio com sua profissão, por exemplo, e também suas ações, só ganham significado se entendidas como em um contexto de interação, complexo, com significados por vezes díspares, heterogêneo, cujo sentido é ativado a partir de visões de mundo que fundamentam sua pessoa. Apenas nas cenas situacionais relembradas é que podemos tentar obter a dimensão do que é ser militar para Paulo.

Não podemos entender, contudo, o que as situações do dia a dia representam para Paulo sem antes estarmos atentos à como ele construiu sua identidade. Sua carreira não começou com seu ingresso na vida militar. Ela se iniciara antes, na socialização dentro do seio familiar, com influência direta do seu pai: "venho de uma família de militares e desde pequeno acompanhei a vida de sacrifício do meu pai, as constantes mudanças, a dificuldade em criar vínculos, as dificuldades financeiras... mas sempre tive em meu pai meu exemplo de caráter, de honra e amor à profissão... sempre me recordo de meu pai me levando ao quartel, de 'mim' brincando de 'ser' soldado, dele me ensinando os valores inerentes à profissão militar: patriotismo, camaradagem, sentimento de cumprimento de missão, acima muitas vezes de nossos próprios interesses; honra, coragem física para muitas vezes enfrentar situações de risco que ponham nossa vida em perigo, e moral, para sempre cultuarmos a verdade, ainda que a mesma venha a nos prejudicar em algumas situações... acho que fui privilegiado de ter sido filho de um pai com tantas crenças e valores, que forjou o homem que sou hoje... sei que jamais serei como meu pai, meu ideal de perfeição como pessoa".

Após uma pausa, Paulo continuou. Para ele, embora a influência do pai tenha tido consequiências dúbias, sendo representada ora como "pressão incômoda", que tentava lhe influenciar para a carreira, e ora como peça fundamental na sua formação de caráter, a decisão pela profissão é traduzida como um sonho de criança e, paralelamente, o momento do efetivo ingresso na vida militar é sentido como algo bom. À época do seu concurso, Paulo havia terminado um relacionamento e seus pais tinham acabado de se divorciar: "eu entrei em depressão profunda aos 21 anos por causa de uma garota que eu namorei e outras coisas... bem, quando meu pai voltou para o Sul, somou tudo: divórcio, término do namoro e a faculdade de Direito que eu odiava... e eu sempre levei a vida muito a sério. Cara, o que me 
curou foi a vida militar... eu tomava antidepressivo antes de ir para o treinamento... eu passei o inferno durante a formação... eu era perseguido por que era universitário, falava inglês... entrei com $70 \mathrm{~kg}$ e saí com 59... na primeira semana, tentaram de tudo para eu ir embora. Carreguei mochila com bloco de concreto, tinha altos e baixos, por conta do efeito colateral do remédio, muito sono... terminou a primeira marcha e eu apaguei e só acordei dois dias depois no hospital... tinha instruções de luta em que lutava, ou melhor, apanhava... mas não é questão de apanhar, mas de controlar seus impulsos de agressividade”.

Interessante é notar que, neste processo de socialização, todas as experiências negativas são transformadas em elementos de caráter positivo. A rigidez da formação militar virou a cura para a depressão. A pressão familiar, que em outros momentos é sentida como sufocamento ou mera coincidência - "o fato de ser filho de militar foi só coincidência... desde moleque eu sempre fui fascinado com isso, só brincava com isso... sempre tive fascínio... lembro de acompanhar a primeira Guerra do Golfo pela TV"-, em geral é relembrada como motivador para realização de um sonho pessoal, dando o tom da leitura do seu próprio caráter: “eu sou movido por superação... cara, eu superei tudo! Até então eu nunca tinha me sentido ligado a nada, deslocado, sabe? Só que sempre tive um forte sentimento de querer ajudar os outros e ao mesmo tempo fazer parte de um grupo que fizesse coisas extraordinárias".

Esta parcela da sua auto-identidade, de acordo com Giddens (2002), deve ser entendida como não sendo simplesmente o resultado de ações, mas algo criado e sustentado rotineiramente nas suas atividades reflexivas e interacionais cotidianas, "o $\mathrm{eu}$ compreendido reflexivamente em termos da sua biografia" (Giddens, 2002, p. 54), de modo que qualquer identidade é moldada socialmente no tempo e no espaço: o indivíduo constrói e mantém reflexivamente sua identidade - o projeto reflexivo do eu - em busca da segurança ontológica para sua vida, impossível sem a manutenção desta biografia coerente.

Assim, a construção de uma biografia coerente, de uma visão de mundo positiva dotada de sentido, base do seu caráter, deu a Paulo uma identidade militar que sintetiza a possibilidade manter em andamento uma narrativa particular, cuja consciência reflexiva, enquanto faculdade que os agentes têm de fazer interpretações sobre a natureza e razões dos seus comportamentos e experiências, é a base para o sentimento de segurança ontológica que os indivíduos constroem como respostas para o seu cotidiano. Para atingir este sentimento, não apenas suas memórias adquiriram o tom positivo: Paulo construiu e constrói uma visão idealizada e americanizada da vida militar, coerente em relação a sua trajetória individual e a figura - também relembrada idealisticamente - do seu pai, mas desconectada da realidade 
cotidiana: "o problema são os choques entre o meu ideal militar e a realidade. Meu ideal são as forças especiais, o profissionalismo, a abnegação, o sacrifício... você lendo os livros que os caras escrevem vê que eles estão ali por algo a mais. Não é pelo dinheiro. Não é pela fama. É fazer parte de algo maior. Fazer parte de um grupo de homens especiais com dons especiais: cumprir missões, ficar dias sem dormir, enfrentar qualquer tipo de coisa. A realidade é o que enfrento todos os dias: tropa desmotivada, amadorismo, imbecilidade dos oficiais. Eu devia ter nascido nos Estados Unidos... Militarismo lá é religião”.

Embora sua idealização permaneça como um sinalizador tanto das experiências positivamente julgadas, quanto do quadro mais geral da profissão que ele abraçou, é no contato com a hierarquia que sua identidade militar sofre arranhões. Dentro de um plano de fundo no qual prevalece a heterogeneidade e a complexidade, a negociação de realidades díspares é central na constituição da biografia particular do agente social. As realidades interpenetram-se de modo que a coerência de uma biografia tende necessariamente a articular vozes contraditórias dentro de um mesmo trajeto. O "Paulo militar" é também um "Paulo acadêmico", por exemplo, e, embora a formação superior seja igualmente um sonho, estar em uma universidade cria uma realidade de conflitos identitários que ele próprio definiu: "cara, eu sou bolado com o pessoal de faculdade por que a maioria é antimilitar... sinto olhares diferentes na universidade por causa disso, principalmente dos professores".

A construção da sua biografia a partir de fragmentos de experiências individuais fragilmente conectados, cujo centro de convergência das preocupações é a manutenção da continuidade da identidade e da coerência daquilo que o distingue como agente social, envolve necessariamente o diálogo entre esferas contraditórias: desde os planos mais rasos, como encarar o pai com sentimento de leve desgosto e, ao mesmo tempo, de admiração pela influência na escolha da carreira, até os planos mais profundos, entre a realidade militar com suas hierarquias - e a idealização da profissão - através das memórias e opiniões próprias -, são esses "choques" o elemento de tensão no dia a dia de Paulo. Se o passado e futuro aparecem idealizados, é o presente que irradia ansiedade: "cara, você vê os soldados em filmes americanos... são 'os caras', saca? A maioria dos meus amigos 'dão' um banho nos superiores... eles precisam de nós, mas é um relacionamento do medo, por que qualquer coisa ameaçam punir. A gente não tem liberdade de ação para nada. Somos água e óleo... os oficiais são fracos na maioria e se escondem atrás do regulamento, impondo um respeito pelo medo. Qualquer coisa é punição". 
Entre a idealização americanizada de uma vida militar, construída reflexivamente para dar sentido e coerência às suas experiências, e as relações hierárquicas com os oficiais, que transformam e chocam seu ideal militar com uma realidade sentida como um "apartheid velado", Paulo passou a definir a hierarquia e seu papel subordinado de maneira ativa em algumas situações que viveu. Situacionalmente, os aspectos positivos e negativos são atualizados de acordo com o contexto em questão. Segundo sua própria fala, por exemplo, em contexto de paz, ele não costuma - e, na verdade, lhe é proibido - argumentar contra as ordens que lhe são impostas, ao passo que em missões reais, como no Complexo do Alemão, "querendo ou não os oficiais dependem e muito dos seus soldados", de maneira que a relação hierárquica adota tons acinzentados dependendo da situação: "tem oficial que é mais aberto e tem maneiras e maneiras de se falar... mas no morro muitos ficaram bonzinhos... só são brabos quando em segurança".

A relação de Paulo com a hierarquia não é estática. Primeiro, ele diferencia os contextos de paz dos de missão, sobressaindo, do último, dentre outros, a ocupação do Complexo do Alemão. Nas situações de "guerra", questionar a relação hierárquica e as ordens tornou-se, em geral, uma possibilidade e, por vezes, uma realidade, contribuindo para a rejeição dos oficiais como um grupo sentido negativamente e, ao mesmo tempo, como um modo de afirmação da identidade grupal dos praças graduados. Em outras palavras, partindo dos conceitos Robert Park (1916), os praças constituem um we-group, que se contrapõe ao other-group formado pelos oficiais: “a relação de camaradagem e paz no grupo 'nós' e a de hostilidade e guerra contra os grupos dos outros são correlativas uma com a outra. As exigências de guerra com os forasteiros são o que garantem a paz no interior [...]" (Park, 1916, p. 58).

Guardadas as devidas proporções, o par conceitual de Park descreve uma relação de conflito que se estabelece na interação entre grupos díspares, o que fora caracterizado como "apartheid velado" por Paulo. A relação hierárquica entre oficiais e praças acontece, ao menos na visão deste agente, nas situações de missão, como uma construção legítima, porém, potencialmente conflituosa em função da caracterização dos oficiais, sendo possível o questionamento das ordens entendidas como não plausíveis, mesmo esta atitude significando possibilidade de punição. Este primeiro aspecto do modo como Paulo, enquanto praça graduado, sente a relação hierárquica fica claro na seguinte cena situacional: "no Alemão, não podíamos comer nada enquanto estivéssemos na rua. Aconteceu de ficar 8, 10 horas sem comer nada, no sol, e superior dando bandinha de viatura pra lá e pra cá, clicando os outros. 
Uma vez, ficamos uma madrugada inteira na posição. Perto da alvorada, passou um padeiro e viu nossa situação deplorável. Ficou com pena e deu uns pães pra gente... éramos proibidos de aceitar qualquer coisa de morador, mas não tínhamos ceiado na noite anterior. Aceitei o pão... o cabo do meu grupo de combate pediu para levar alguns pães na posição de outro grupo de combate que também não devia ter comido... eu autorizei. Nisso chega o superior e a primeira coisa que ele perguntou era aonde estava o cabo, por que ele percebeu que tinha um a menos na posição. Eu poderia ter carteado e dito que ele fora ao banheiro, mas eu tava tão puto que falei 'pois é, não recebemos ceia na posição... um paisano ficou com pena e deu pão'. Daí, ele surtou: ‘Porra! Vocês não sabem que não é pra pedir comida dos outros?'; falei: 'pois é! Mas quem dá essas ordens imbecis 'tá' num ar-condicionado felpudo agora... é muito fácil ficar dando banda de viatura enquanto os soldados ficam 10, 12 horas sem poder tirar o capacete, encostar...'. Eu poderia ter sido preso naquela hora! Mas é aquela... missão real, guerra, querendo ou não os oficiais dependem muito de nós".

A definição da hierarquia, que a princípio parece rígida e inquestionável na vida militar, recebe outro tratamento nas situações que Paulo descreveu como missões reais. No quartel, segundo ele próprio, se a situação no Alemão tivesse ocorrido no cotidiano, "quando a ordem é plausível... bem, não questiono e nem posso, nem quero questionar ordens no geral. Nunca fui punido, mas se fosse numa situação normal no quartel... no dia a dia... eu teria recebido uma...”, ao passo que na missão, sobre questionar ordens, “imbecilidades, eu falo!”. Entre a vida no quartel e a missão real, é a situação que define o contexto hierárquico. A estrutura mais compacta e inquestionável das ordens no cotidiano, cujo desrespeito é punido, na missão real, admite uma negociação da realidade hierárquica entre subordinado e superior, entre praça graduado e oficial, através de uma via de mão dupla cujo sentido da ordem é discutido. As variáveis em cada situação, de paz ou de "guerra", configuram a plausibilidade de se obedecer a uma ordem ou discuti-la.

Piero Leirner (1997) argumentou que a hierarquia militar não é um sistema em forma de pirâmide, mas um "princípio segmentador - e não somente entre patentes, mas de pessoa a pessoa" (Leirner, 1997, p. 72). Metaforicamente representado como uma fila indiana, ele é construído como uma ordem classificatória que destaca, cria e organiza as diferenças entre os indivíduos a partir da ideia de precedência, cuja cadeia de comando e sanções disciplinares impõem obediência total e imediata às ordens dos superiores. Esta característica aparece clara no discurso de Paulo quando se trata, como dito, do dia a dia de paz no quartel. Fato curioso é que para realizarmos as entrevistas cujo material dá base a este trabalho, por exemplo, Paulo 
teve que pedir autorização aos oficiais responsáveis a que se subordina, e o fez sem qualquer questionamento hierárquico, sendo extremamente incisivo ao me pedir que ocultasse quaisquer possibilidades de identificação da sua pessoa no decorrer do trabalho: as situações poderiam ser descritas, mas eu não poderia, por exemplo, entrar em detalhes extremamente pessoais que pudessem caracterizá-lo. Fica claro que a relação de precedência do imediato superior ao imediato subordinado, cuja obediência é a regra, permaneceu fixa e inalterada, ao passo que na cena do padeiro no Alemão, a negociação foi possível: embora concordemos com Leirner, o discurso de Paulo demonstra que a hierarquia, o comando e a ordem de precedência só se mantêm independente de alteração em situações específicas, ao passo que em outras contextos, nas missões reais, a ordem de pessoa a pessoa pode ser questionada e negociada sem quaisquer danos provenientes da discussão, mantendo-se, obviamente, limites que impedem o exagero, como o próprio Paulo definiu: “ 'po', não é que a hierarquia seja relativizada não... mas tem oficial que é mais aberto também, né? E tem oficial que não faz nada sem consultar os praças graduados... mas na situação real eles ficam tranquilinhos... e eu já tenho fama de marrento mesmo...".

Se, por um lado, a identidade militar e, em específico, a de praça é construída dialogicamente e mantida reflexivamente, a partir das interações que Paulo teve e tem na sua vida - principalmente com um viés de defesa da visão de mundo do we-group, da sua rede efetiva, em função dos choques com o other-group dos oficiais - e do antagonismo entre a realidade e sua carreira militar idealizada, por outro, a categoria da hierarquia, com seus polos de ordem e obediência, também é definida no jogo da cena, a partir das interações que se estabelecem em contextos específicos. Intimamente ligadas, identidade militar e hierarquia são dois conceitos que se definem e se mantém nas situações. Vejamos, agora, o tema da moralidade.

"Eu sempre fui muito idealizador... culpa da minha mãe que queria me criar bom moço, eu acho", comentou Paulo quando novamente indagado sobre a carreira militar como um todo e, em especial, sobre lembranças da invasão do Alemão. "Cara, o mundo militar não é perfeito... mas o meu é! A vida militar que eu idealizo. 'Me frustro' diariamente... oficiais principalmente... a minha carreira militar é justamente o processo pelo qual passei e que me tornou quem eu sou hoje. Cara, foi um aprendizado que não tem como explicar! Auto- 
aprendizado, autoconhecimento, conheci meus limites de corpo e mente.... os laços de amizade também são indissolúveis... tanto que minha ex falou que eu era um Paulo e que, depois do treinamento e da formação, voltei outro... fiquei muito autoconfiante em tudo!”.

Paulo continuou: "nossas forças estavam muito despreparadas para essa missão [a do Alemão], assim como está para outras. O que posso te adiantar é que da metade para o final fiquei muito agressivo e 'tava' quebrando o pau todo o dia lá... mas sou muito controlado. Muita briga, discussão, porrada... muito marginal! Cara, foi muito surreal a missão! Bêbado desafiando tropa, motoqueiro que jogava moto pra cima dos meus soldados... teve um que ficou dando de brabo, desci ele da moto na porrada porque ele quase atropelou um soldado! Mas eu tentava manter a sanidade. No final, 'tava' rezando para acabar!’. Perguntei, então, se ele se arrependia de algo: "Eu sentia que 'tava' fazendo algo de bom, por que sabia que não era ninguém santo ali. Eu não consigo ver injustiça e ficar olhando. Não era nada em excesso também, não deixei ninguém roxo. A gente usa o mínimo de agressividade para dominar a situação".

"Mas, quem você estava protegendo? Quem você sentia que estava protegendo?", indaguei. "A cidade do Rio de Janeiro. O morador da comunidade. Todo dia alguém tentava dar algo como forma de agradecimento, mas como eu não podia aceitar eles ficavam meio que chateados... ou vinham denunciar boca de fumo... teve uma situação, por exemplo, que um menor de idade veio chorando na minha direção. Falou que o pai 'tava' espancando a mãe. $\mathrm{O}$ meu superior imediato 'tava' do meu lado... daí eu falei ‘e aí, chefe? Qual a ideia?', ele falou: 'caga'... o menino chorando, me olhando com olhar de 'ei, você é um soldado! São heróis!'... e o superior, nada. Na terceira, eu olhei para o menino e para meu superior e falei 'o senhor pode cagar, mas eu não consigo!'. Eu sempre tenho dificuldades em não me envolver emocionalmente. Sou marido, filho, logo me coloquei no lugar do garoto e não pude me conter. Peguei um cabo e dois soldados alimentados a fubá e todinho e partir atrás do cara. Sorte dele que não pegamos, mas peguei a mulher e levei 'na' delegacia. Falei para ela denunciar, Lei Maria da Penha e tal. Ela tinha abandonado o cara e voltou só para pegar os pertences. Depois o superior veio com sermão, mas eu falei 'olha, eu seria um babaca se 'tivesse' perdendo três meses da minha vida aqui e fosse um omisso. Não vim voluntário para o Alemão para passear”.

Sobre outra situação, Paulo assim a relatou: "Bom o episódio do travesti foi meio engraçado... a gente 'tava' fazendo a segurança de uma instalação quando um subordinado meu viu um vulto... a instalação era considerada área militar, inclusive. Fomos lá ver qual é... 
como estava escuro e todo mundo meio nervoso, tomei a iniciativa por ser o comandante e levei comigo a espingarda com munição de borracha, até mesmo por saber que em situações como essa os soldados têm o dedo frouxo e saem logo disparando... assim que cercamos as pessoas, mandei se identificarem... na mesma hora todos ficaram congelados... como estava escuro e só vi a silhueta percebi que eram dois menores de idade e o que parecia ser uma mulher, pois estava trajada com um vestido colado, cabelos longos, baixa... aí, perguntei: 'você é o que? Homem ou mulher?'... po, os soldados logo se seguraram para não rir! O 'elemento' respondeu com uma voz baixa e fina: 'sou homem'. Logo percebi do que se tratava: aliciamento de menores! A travesti começou a gaguejar e se enrolar na resposta... falou que não fazia nada... que chamou os menores para conhecer uma garota e tal... sabendo que era mentira eu comecei a 'apertá-la' para contar a verdade. Aí, um subordinado meu chegou e me chamou num canto: 'senhor, enquanto vocês vinham pelo lado escuro, eu dei a volta e cheguei um pouco antes, pude ver que o travesti estava agachado chupando os meninos...'. Digo meninos porque os dois tinham por volta de 13 anos, não mais que isso... não segurei e tive um acesso de cólera, raiva mesmo! Eu não consigo conceber de forma alguma estupradores e pedófilos! Po, sou marido, irmão, tio, me considero um homem apegado aos valores cristãos e prezo muito a família. Aí, comecei num tom mais ríspido e agressivo a perguntar se achava que eu era idiota e se achava que eu 'tava' acreditando nas 'estorinhas' dele... antes que ele respondesse com outra mentira, terminei por dar um tapão no meio da cara dele... meus soldados ficaram em silêncio... em seguida liguei para meus superiores e dei voz de prisão em flagrante delito por estupro de vulnerável... ele foi encaminhado para a delegacia e os pais dos meninos foram chamados para buscarem seus filhos".

Nas duas situações, parece ter sido a identidade militar idealizada, moralizada, do soldado como herói, como representante da ordem, que guiou as ações de Paulo. A questão da moralidade aparece a partir daquele conjunto de atores heterogêneos interagindo a partir de posições diferentes. Para Paulo, fazia parte do trabalho identificar os "bandidos", e ele os caracterizava afirmando que "você conhece o vagabundo pelo modo de andar. Não é uma questão racial, apesar de que muitos deles eram negros. Embora eu suspeitasse de todo mundo, confiava só nos homens do meu pelotão, mas o perfil do marginal é aquilo: chinelo, bermuda, boné virado para trás, cara de bandidinho, gírias, muitas gírias... mas é aquilo: a maioria você reconhece pelo jeito de andar mesmo... você simplesmente sabe". 
Identificando esses agentes, a partir da sua lógica e visão de mundo descrita acima e da sua posição de empreendedor moral impositor de normas e regras, eram os valores de Paulo que se tornavam a bússola de significado para suas ações e acusações. Sem perder de vista que eles detinham o poder, elementos como agressividade, heroísmo, valores cristãos e pessoais, eram definidos na situação para significar as atitudes. Segundo Howard Becker,

\begin{abstract}
As pessoas convertem valores em regras específicas em situações problemáticas. Elas percebem alguma área de sua existência como problemática ou difícil, exigindo ação. Após considerar os vários valores que a subscrevem, elas escolhem um ou mais como pertinentes a suas dificuldades e deduzem deles uma regra específica. A regra, formulada para ser coerente com o valor, enuncia com relativa precisão quais ações são aprovadas e quais são proibidas, as situações a que a regra é aplicável e as sanções associadas à sua infração (Becker, 2008, p. 138).
\end{abstract}

Nas duas situações descritas, fica clara a racionalização e a visão de mundo que Paulo empregara. Seja como um herói cuja agressividade era permitida no contexto de conflito e legitimada por ser um representante da ordem e da lei, seja como um pai ou marido que se colocou na posição dos meninos, no caso do travesti, sua visão de mundo e lógica própria definiram as ações com total coerência e sem arrependimento. Usar a força física não se tornou um elemento imoral ou amoral, mas antes legitimado e necessário para "dominar a situação" na interação com os desviantes assim considerados por ele. Ainda na linha argumentativa de Howard Becker, como o ato desviante é definido na interação entre os atores sociais, ele é definido polissemicamente, cujos sentidos se amoldam uns aos outros a partir de acusações - o desvio não é uma categoria abstrata, mas concreta, definida em cena -: de um lado, ir atrás do pai do menino que espancava a mãe sobressai como uma ação cujo valor de guia é o heroísmo que o próprio pedido de ajuda confirmava. De outro, bater no travesti, usar a violência quando conduzi-lo à delegacia sem o "tapão no meio da cara" seria o legalmente correto, justifica-se na visão de mundo de Paulo através de acusações que se pautam nos seus valores cristãos e pessoais, parte daquela identidade militar construída desde cedo. O próprio questionamento da hierarquia e o uso justificado da violência em diversos outros momentos do seu discurso desenrolam-se não como legítimos ou corretos de forma objetiva, mas apenas definidos a partir daquelas situações específicas: usar a violência e questionar ordens só possuem crédito na missão no Alemão, por exemplo - “o desvio não é uma qualidade do ato que a pessoa comete, mas uma consequência da aplicação por outros de regras e sanções a um 'infrator”' (Becker, 2008, p. 22). 
A questão central não é a categoria desvio como algo descolado do ato, mas como consequência das reações das pessoas a certos comportamentos de outras e da definição da situação via acusações que dão base àquelas normas. Mas Paulo vai além: "bandido não tem moral. Para mim, assassinar, sequestrar, estuprar, aliciar menores, bater na mulher... acho que não tem como ser considerado moral... bandido é bandido. Há vários motivos para eles fazerem o que fazem, muitos são levados pela falta de opção, falta de empenho do governo... porém não acho que seja desculpa para tal. Tem muita gente honesta que ganha uma miséria, mas mantém sua dignidade trabalhando honestamente, buscando outras opções. Cara, penso que simplesmente há homens maus no mundo e eles precisam ser lidados apropriadamente".

A nova dimensão que Paulo acrescenta é a questão da existência de uma moral objetiva, externa aos atos, social por excelência. O próprio Becker chama-nos atenção para esta outra dimensão, muito embora sua lupa sociológica esteja focada nas regras de acusações e interações que definem a moralidade nas cenas concretas ${ }^{2}$. Se, por um lado, a acusação e a interação definem a moralidade que dá o tom do significado das ações dos agentes, por outro, estas não estão descoladas das regras sociais mais gerais. Como, então, acoplar as duas dimensões que aparecem, inclusive, nas falas de Paulo?

Partindo de um nível mais geral da teoria de Durkheim sobre a moral, há uma dicotomia que o autor francês elucida extremamente eficaz para as cenas aqui descritas. Segundo o mestre francês, a realidade moral possui dois aspectos: um objetivo e outro subjetivo. O primeiro, a moral objetiva, são as normas que regem a sociedade e que se baseiam nos preceitos do que é certo ou errado, regras entendidas como sustentáculo da própria vida em comunidade, fato social em si, coercitivo, exterior ao indivíduo, normas que pautam as aplicações das sanções legais, por exemplo. Já o segundo aspecto, a moral subjetiva, é a interpretação da moral comum pelo indivíduo, que pode inclusive julgá-la como imoral: "cada indivíduo, cada consciência moral exprime a moral à sua maneira [...]. Os aspectos, mesmo os mais essenciais, da moral são percebidos diferentemente pelas diversas consciências" (Durkheim, 1906, p. 48).

Muito embora Durkheim priorize em seu trabalho o primeiro aspecto, o par dicotômico parece ganhar relevo quanto associado à ideia de cultivo de Simmel (1908), na qual há a aproximação de duas esferas: a cultura subjetiva e a cultura objetiva. A dinâmica do processo de cultivo ocorre na tensão entre o externo e o interno, entre a experiência e

\footnotetext{
2 "Não é minha intenção aqui afirmar que somente atos considerados desviantes por outros são 'realmente' desviantes. Mas é preciso reconhecer que esta é uma dimensão importante, que deve ser levada em conta em qualquer análise de comportamento desviante" (Becker, 2008, p. 31).
} 
existência. A cultura só existe se o homem retira para seu desenvolvimento algo que lhe é externo, o que se resume na máxima simmeliana "cultura é o caminho da alma para si mesma" (Simmel 2005, p. 77). No sentido pleno, a unidade social só aparece na interação entre cultura subjetiva e cultura objetiva, sendo que a primeira prevalece como ápice do processo, a partir do qual entendemos que a moral objetiva pode ser vista como pertencente à esfera da cultura objetiva, e a mural subjetiva, à cultura subjetiva.

A passagem do simples para o complexo não se processa por dicotomias igualitárias, mas por dicotomias valoradas, diferenciadas. Com o crescimento e especialização da cultura objetiva (todas as obras humanas como arte, direito, tecnologias, moral - valendo ressaltar que é o próprio Simmel quem incluiu a moral neste universo objetivo - etc.), tais objetos adquirem um valor objetivo (em relação a eles próprios) que resvala em uma perda de cultura subjetiva, já que seu possível valor cultural, o que eles representariam para e no cultivo, perde em significação para os sujeitos: há um distanciamento entre as duas esferas culturais e o cultivo torna-se deficitário. As coisas podem tornar-se mais lógicas, mas o cultivo dos sujeitos não cresce proporcionalmente. Por fim, ocorre uma separação entre a produção cultural objetiva e o nível cultural subjetivo:

\footnotetext{
Things become more perfected, more intellectual, and to some degree more controlled by an internal, objective logic tied to their instrumentality; but the supreme cultivation, that of subjects, does not increase proportionately. Indeed, in view of the enormous increase of objective culture, in which the world of things is parceled out to countless workers, subjective culture could not increase. [...] The dissonance of modern life - in particular that manifested in the improvement of technique in every area and the simultaneous deep dissatisfaction with technical progress - is caused in large part by the fact that things are becoming more and more cultivated, while men are less able to gain from the perfection of objects a perfection of the subjective life. (Simmel, 1908, pg. 234)
}

O coroamento dessa dissonância é o famoso caráter blasé que Simmel (1903) tipifica como uma característica do homem metropolitano, o embotamento do sujeito em si mesmo para se distanciar da enorme quantidade de estímulos nervosos que o atingem, consequiência da desvalorização cultural do mundo objetivo. No tocante à questão da moral, por conseguinte, a partir da dicotomia durkheimiana de moral objetiva e moral subjetiva, o distanciamento dos agentes sociais da possibilidade intermitente de cultivo traduz-se como um império da moral subjetiva situacionalmente considerada e, muitas vezes, "não-cultivada", funcionando como o vetor principal da qualificação e significação das ações nas situações definidas: torna-se fraca a referência plena e abrangente à moral objetiva, do certo e do errado aceitos e impostos socialmente, configurando-se unicamente a moral do ponto de vista 
subjetivo na cena, deficitária por fazer parte da cultura subjetiva igualmente capenga em razão da dissonância da vida moderna.

Nas situações que Paulo descreveu, embora o uso abusivo da força e da violência sejam efetivamente - e legalmente - condenados e, em certos contextos, sentidos mais amplamente como imorais, a atualização nas cenas da missão real, como no caso da agressão ao travesti quando bastava levá-lo para a delegacia, consolida-se via a acusação e a interação situacional, tal qual definido por Becker, sem o agente dar atenção ou valor maior à moral objetiva, que, embora se mantivesse como norte orientador da moral subjetiva, pois internalizada até certo ponto, perdia espaço na lógica de Paulo diante da sua identidade militar, dos seus valores e realizações, verdadeiros parâmetros de julgamento das suas ações. Aliciar um menor, espancar a esposa e tráfico de drogas subsistiam como mais imorais do que a utilização desnecessária da força física para reprimi-los, e não como tão imorais quanto as suas ações se avaliadas nos termos da moral objetiva, fato que assim conferia, na sua visão de mundo, justificativa para seus julgamentos situacionais.

Voltando a Simmel, a questão que se coloca é que a definição do que é moral ou não na situação depende necessariamente dos valores cultivados nos agentes sociais. Outrossim, é na simbiose entre a moral objetiva e subjetiva, simbiose esta atravessada pela impossibilidade de se continuar o processo de cultivo visto a dissonância das esferas objetiva e subjetiva da cultura, que situação e estrutura social definem-se. Os julgamentos morais que Paulo fez são tanto expressão dos valores que the foram inculcados, quanto definições atualizadas na situação, cujo contraponto que poderia frear seus julgamentos e ações - a moral objetiva esvaneceu-se graças distância traduzida na atitude blasé. Bater no travesti ou espancar um motoqueiro que tentou atropelar um soldado, por exemplo, é julgado interacionalmente como desviante e, por isso, passível de sanção e imoral em última análise, não apenas pelas forças da situação que agiam, mas inclusive com respaldo, um espelho de uma certa justificativa mais geral que se pretendia e parecia existir, na sua visão, para além da situação. O problema, insolucionável, é a tragédia da cultura: evitar estes excessos tão imorais quanto às atitudes que eles pretendem reprimir depende, necessariamente, do cultivo, do aprimoramento do agente em contato com a cultura objetiva - e, por conseguinte, com a moral objetiva. Se, no entanto, este contato está impossibilitado graças a perda de valor cultural do mundo objetivo, a consequência é que os julgamentos morais ganham justificativa apenas na definição da situação na qual a visão de mundo e as interações são sua base de avaliação principal: os 
excesso, assim, reluzem como morais na lógica e na visão de mundo do agente, mesmo que percebidos, em outros contextos, como imorais.

Contudo, há possibilidade julgamento moral sobre os excessos: para além da percepção da lógica moralmente construída do agente, os excessos podem ser taxados de imorais quando vistos de fora por outros agentes ou até pelo mesmo quando confrontados com outros valores, exatamente por que a moral subjetiva difere de consciência para consciência. Dependendo do cultivo de cada um, da internalização da moral objetiva que dá substrato para a subjetiva, da visão de mundo e da biografia pessoal, a possibilidade de julgamento de valores dá-se no nível de outras situações e cenas, como, por exemplo, na interação do ouvinte com o relato que lhe está sendo contado, dimensão que sobra para avaliação de cada um.

Paulo, claro, não é um carrasco. Tudo que fez no Alemão remete necessariamente a sua visão de mundo, a sua identidade definida sempre na interação e na cena. Há uma coerência nas suas ações e justificativas. O dever do antropólogo, longe de julgar, é absorver e tentar entender estas escolhas, na complexidade das situações em que ocorrem. Moral, identidade e hierarquia, por fim, definem-se situacionalmente, mas não estão desconectadas, embora tragicamente insensíveis, da possibilidade de aprimoramento a partir da ideia de cultivo simmeliano.

"Cara, até que tô começando a me interessar sobre essas paradas filosóficas...", finalizou Paulo, sobre meu trabalho. "Sei que quando ficar mais velho terei muita história para contar... mas ninguém vai acreditar".

\section{Referências Bibliográficas}

AGIER, Michel. 2001. "Distúrbios identitários em tempos de globalização". Mana: estudos de antropologia social. vol.7, n.2, pp. 7-33.

BARTH, Fredrik. 2000. A análise da cultura nas sociedades complexas. In: O guru, o iniciador e outras variações antropológicas. Rio de janeiro: Contra Capa Livraria.

BECKER, Howard S. 2008. Outsiders: estudos de sociologia do desvio. Rio de Janeiro: Zahar. 
DURKHEIM, Émile. 1906. "Determinação do fato moral”. In: DURKHEIM, Èmile. 1970. Sociologia e Filosofia. Rio de Janeiro e São Paulo: Forense, 1970. pp. 43 - 69.

EPSTEIN, A.L. 1969. “The network and urban social organization”. In: J. C. Mitchell (ed.), Social Networks in Urban Situations. Manchester: Manchester University Press.]

GIDDENS, Anthony. 2002. Modernidade e Identidade. Rio de Janeiro: Jorge Zahar Editor.

LEIRNER, Piero. 1997. Meia Volta Volver - um estudo antropológico sobre a hierarquia militar. Rio de Janeiro: Editora Fundação Getúlio Vargas.

MILLS, Wright. 1982. A Imaginação Sociológica. 6. ed. Rio de Janeiro: Zahar Editores.

MITCHELL, J. Clyde. 1971. "The Kalela dance”. The Rhodes - Livingstone Papers no.27. Manchester: Manchester University Press.

PARK, Robert E. 1916.“A cidade: sugestões para a investigação do comportamento humano no meio urbano”. In: VELHO, Otávio G.(org.).1967. O fenômeno urbano. Rio de Janeiro: Zahar. pp. 29-72.

SIMMEL, Georg. 1903. "As grandes cidades e a vida do espírito". Mana: estudos de antropologia social, 2005, vol. 11, n. 2, pp. 577-592.

. 1908. "Subjective Culture". In: Donald Levine (Org.). On Individuality and

Social Forms. Chicago: The University of Chicago Press, 1971. pp. 227-234. . 2005. "O Conceito e a Tragédia da Cultura". In: SOUZA. Jessé; ÖELZE, Berthold

(orgs.). Simmel e a Modernidade. $2^{\circ}$ ed. Brasília: Editora UnB. pp. 77 - 107.

VELHO, Gilberto. 2003. Projeto e Metamorfose: Antropologia das Sociedades

Complexas. Rio de Janeiro: Jorge Zahar Ed. 2008. Individualismo e Cultura: Notas para uma Antropologia das Sociedades

Complexas. Rio de Janeiro: Jorge Zahar Ed. 2000. "Individualismo, anonimato e violência na metrópole". Horizontes

Antropológicos. Porto Alegre, v. 6, n. 13, pp. 15-29. 